\title{
Exploring the Dromos of Hermes at Hermopolis Magna
}

\author{
Youssri Abdelwahed ${ }^{\mathrm{a}} \quad$ Mamdouh Darwish $^{\mathrm{b}}$, \\ Hassan Osman ${ }^{c}$, \\ a Assistant Professor, Faculty of Tourism and Hotels, Minia University \\ b Professor, Faculty of Arts, Minia University \\ ${ }^{\mathrm{c}}$ Researcher, Faculty of Tourism and Hotels, Minia University
}

\section{Keywords}

Dromos

Hermes/Thoth

Hermopolis Magna

Tertrastyla

Komsterion

Activities

\begin{abstract}
The dromos of Thoth (Hermes) at Hermopolis Magna was the backbone of the ancient city, where it ran from east to west and had the majority of the city's institutions and buildings running on its sides. This paper aims to highlight the historical and archaeological importance of the dromos through analyzing the settlement layout and planning and the major public places built along it and used for different types of activities s uch as healing, dream interpretation, religious celebrations, governmental declarations, and commercial activities. The archaeological remains built alongside the dromos confirm its crucial role in the city's life. Archaeological records and textual evidence allude to the remains of the Gate of the Sun on the eastern side of the dromos, passing through the exedra, the Komsterion near the chapel of the royal cult, the remains of the Tertrastyla, the Bank of Athena, and finally one comes to the Gate of the Moon on the west side of the dromos. Based on archeological and papyrological evidence of Hermopolis Magna, and contrary to previous studies which located the dromos on the north-south axis of the city, this study argues that the dromos ran from the east to the west of Hermopolis Magna.
\end{abstract}




\section{Introduction}

The word dromos ( $\delta \rho$ ó $\mu \circ \varsigma)$ is derived from the Greek verb $\delta \rho \alpha i ́ \sigma \kappa \omega$, which means "to run". ${ }^{1}$ Perhaps the earliest surviving attestation of the term dromos occurs in the Iliad of Homer, where it was used as a place where horses wandering, óvó $\delta \rho o ́ \mu o v .{ }^{2}$ In Athena, the Panathenaic route to the agora was called dromos, where many various races and equestrian events were held. ${ }^{3}$ The dromos was also used by Phaedrus who said to Socrates that he likes to walk on the street as it was more comfortable than walking in the porticoes. ${ }^{4}$ The dromos could also be used in reference to a wide paved street like the dromos of Hermes at Hermopolis Magna, which is the focus of this article. ${ }^{5}$

The dromos of Egyptian temples underwent many architectural developments throughout the ancient Egyptian history. Yet the main functions of the dromos as a processional route and business zone were maintained from the early Dynastic Period (2920-2575 BC) until the Byzantine Period (AD 313-641). As its main function, the dromos served as a sacred route for the religious public processions and a meeting point of the Egyptian inhabitants and worshippers with their deities whilecoming out from the sanctuaries. Such religious and political processions held along the dromos were events, where the spiritual power of the deities was manifested and the power of the ruler to operate the state was displayed. Such annual festivals and religious occasions reflected the importance of the dromos as a place of appearance and an assembly point for the individuals and their deities. As the dromos was a religious and gathering place for the ancient Egyptians, many activities were held along it. Pilgrims and other visitors who came to attend the public and religious procession along the dromos made offerings and supplications to their deities with the help of the priests and workshops that offered their services to the visitor.

It appears that the earliest surviving papyrological reference to the dromos of Hermes at Hermopolis Magna dates back to $89 \mathrm{BC},{ }^{6}$ though it is likely that the dromos existed earlier. This papyrus recounts that the dromos of Hermes used to encompass with three tetrastyla, the premium tetrastylon, the grand tetrastylon (vó $\tau$ ○ $\varsigma$

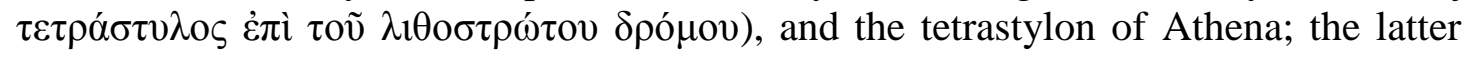
was connected with a chapel dedicated to Athena at Hermopolis Magna. The economic role of the dromos of Hermes appears in its central role in the city and the existence of the Bank of Athena along it. ${ }^{7}$ Other papyrological documents confirm the existence of the stone-paved dromos of Hermes, the thrice great god ( $\pi \rho{ }^{\prime} \varsigma$ [ $\tau \dot{\omega}$

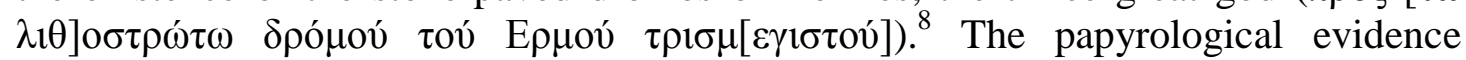
confirms the current ruined constructions that once existed along the dromos, including its limestone paving slabs. ${ }^{9}$ Spencer stated that the dromos is known to have been in existence for nearly 400 years, making its construction date around $240 \mathrm{BC}$, when the sanctuary of Ptolemy III and Berenike was built on the north side of the dromos opposite the Komasterion and near the main temple of Hermes. The repair and renewal of the pavement slabs must have been necessary on several historical areas. ${ }^{10}$

\footnotetext{
${ }^{1}$ Wachsmuth 1887: 466.

${ }^{2}$ Plato, Phdr 23.321.

${ }^{3}$ Camp 1986: 45.

${ }^{4}$ Plato, Phdr. 227a.

${ }^{5}$ Yunnis 2003: 161.

${ }^{6}$ P.Ryl. 2.68.7.

${ }^{7}$ SPP 5.81, 7-8.

${ }^{8}$ P.Amh. 2.98. 2.

${ }^{9}$ Bomman 2012: 66.

${ }^{10}$ Spencer 1982: 39-42.
} 


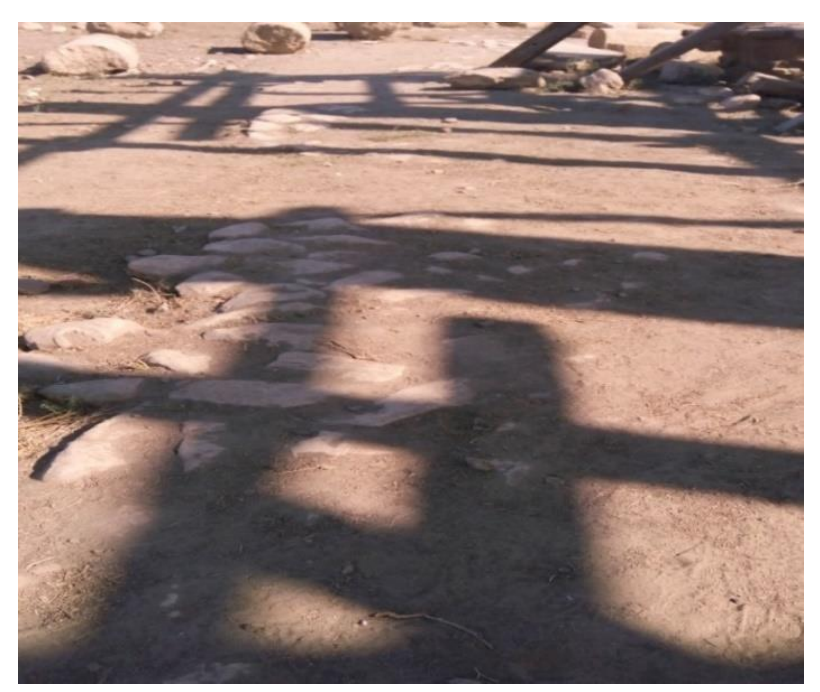

Figure (1): The paved dromos near the Komasterion (Authors' Photograph).

The main east-west street of Hermopolis Magna was always referred to as the "dromos of Hermes". 11 The dromos of Hermes and Antinoe Street respectively formed the main cross and longitudinal streets at Hermopolis Magna through the Graeco-Roman Period (332 BC-AD 641). Like the dromos of Serapis at Alexandria, the dromos of Hermes was paved with slabs of white limestone with irregular measurements, but unfortunately the pavement slabs of the dromos of Hermes were quarried except for the area near the Komasterion. At some portions, the slabs were joined together with a bedding layer of pink plaster. The processional route ran from the Gate of the Sun at the east side to the Gate of the moon at the west side of the city. Many buildings are datable back to different periods which were located at both sides of the dromos. ${ }^{12}$

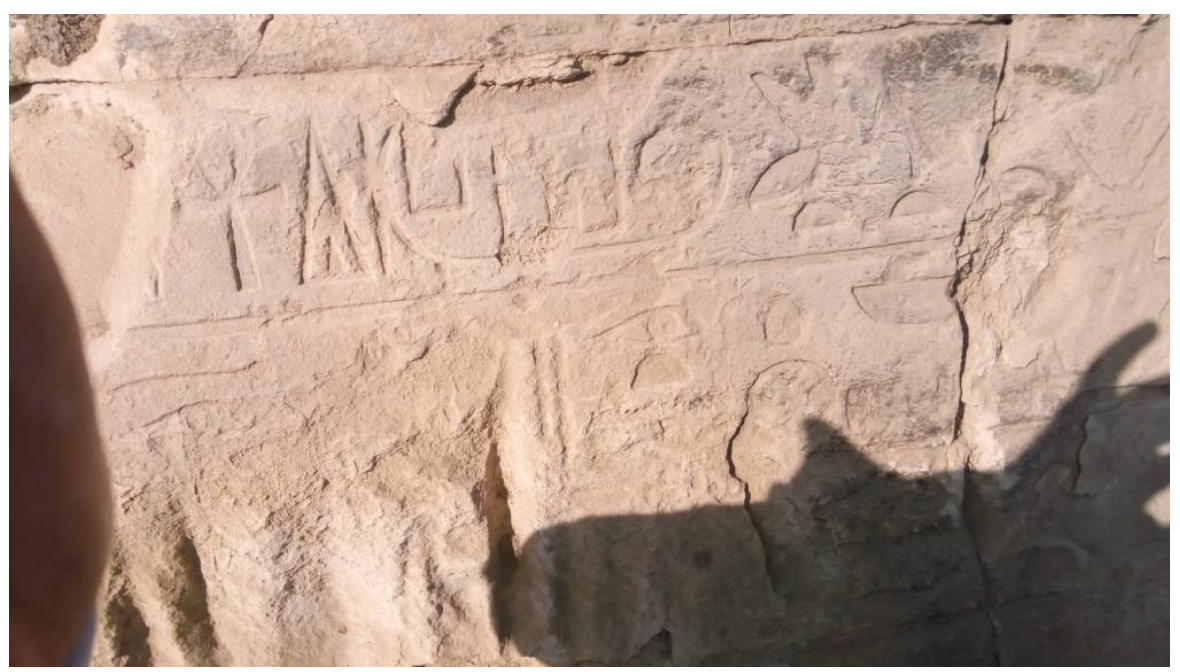

Figure (2): The cartouche of Ptolemy III in the royal cult chapel on the dromos (Authors' Photograph).

\footnotetext{
${ }^{11}$ SPP 5.81.7-8.

${ }^{12}$ Roeder 1959: 40.
} 
The white limestone slabs of the paved dromos are partly preserved near the Komasterion for a distance of approximately seven meters, but the bedding layerof pink plaster was detected up to the remains of the chapel of the deified rulers, Ptolemy III and Bernice. ${ }^{13}$ It seems that the dromos of Hermes underwent its last stage of renovation during the reign of Hadrian, when he erected a chapel to the deified great gods, his beloved companion Antinoe, and himself on the eastern side of the dromos. ${ }^{14}$ The dromos was sometimes named after the chapels built along it like the dromos of Apollo and the dromos of Aphrodite, who were among the great deities in the city. ${ }^{15}$

Based on papyri of the late third-century $\mathrm{AD}$, Bagnall has given a brief description of the topography of the central area of Hermopolis Magna. In his view, the individual who travelled as far upriver as Hermopolis Magna would disembark at its harbor on the Nile, and then traveled west a few kilometers, and arrive at the city through the Gate of the Sun. The street leads west would offer the traveller a familiar scene common to hundreds of the eastern cities of the Roman Empire. Colonnades were lined along the dromos, leading the pedestrian through a tetrastylon, past an exedra and the temples of Aphrodite and Tyche, through the Great Tetrastylon where the avenue leading to the great temple of Thoth crossed Antinoe Street, through a third tetrastylon of Athena, and so on to the Gate of the Moon on the west. ${ }^{16}$

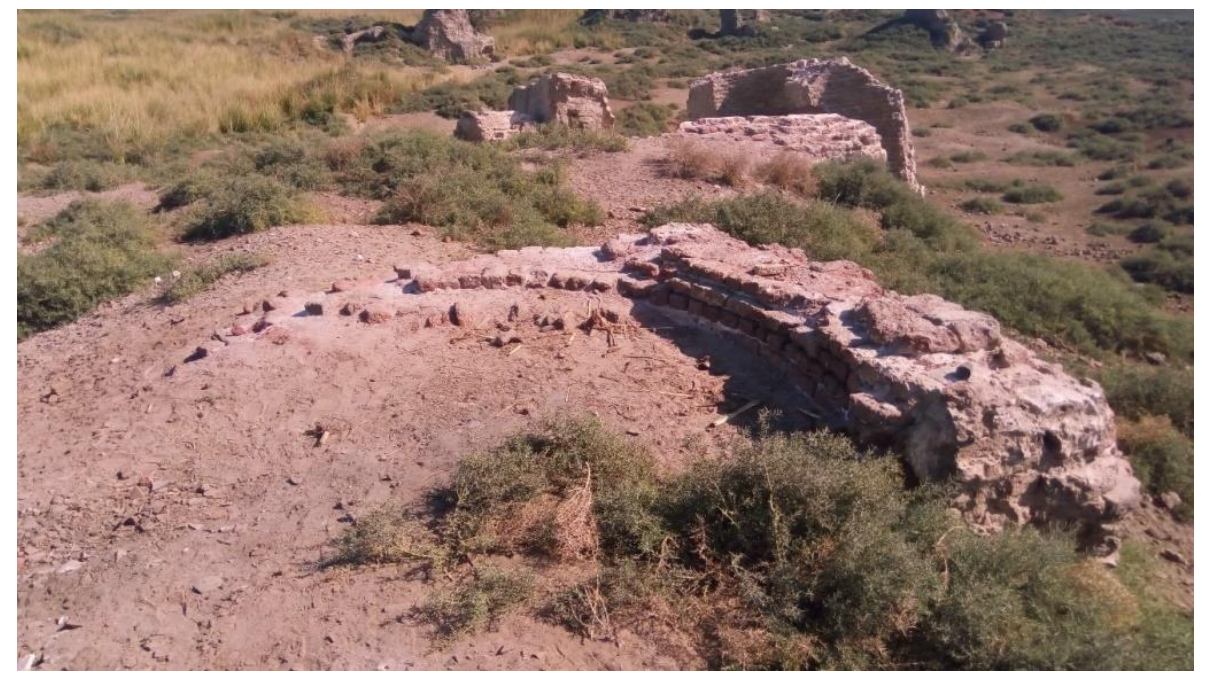

Figure (3): The remains of the exedra on the south side of the dromos (Authors' Photograph).

Greek papyrological documents seem to suggest that the dromos was the main east-west street of the Graeco-Roman city of Hermopolis Magna. The dromos of Hermes intersected the north-south street of Antinoe, where the intersection was marked by a great tetrastylon, which was probably built during the time of Marcus Aurelius. ${ }^{17}$ Like the main dromos of great Serapis at Alexandria and the dromos of the Serapeum at Oxyrhynchus, the dromos of Hermes had two main gates, one of them was located at the eastern side, which was called the gate of the Sun or Helios

\footnotetext{
${ }^{13}$ Spencer 1982: 34 .

${ }^{14}$ Roeder 1959: 108.

15 Bomman 2012: 62.

${ }^{16}$ Bagnall 1993: 45.

${ }^{17}$ Bailey 1991: 29.
} 
Gate ( $\dot{\eta} \pi \hat{v} \lambda \eta \tau$ นõ $H \lambda$ íov) and other gate on the western side was named the Gate of the Moon or Selene Gate $(\pi v ́ \lambda \eta \Sigma \varepsilon \lambda \eta v i \alpha \kappa \eta) .{ }^{18}$
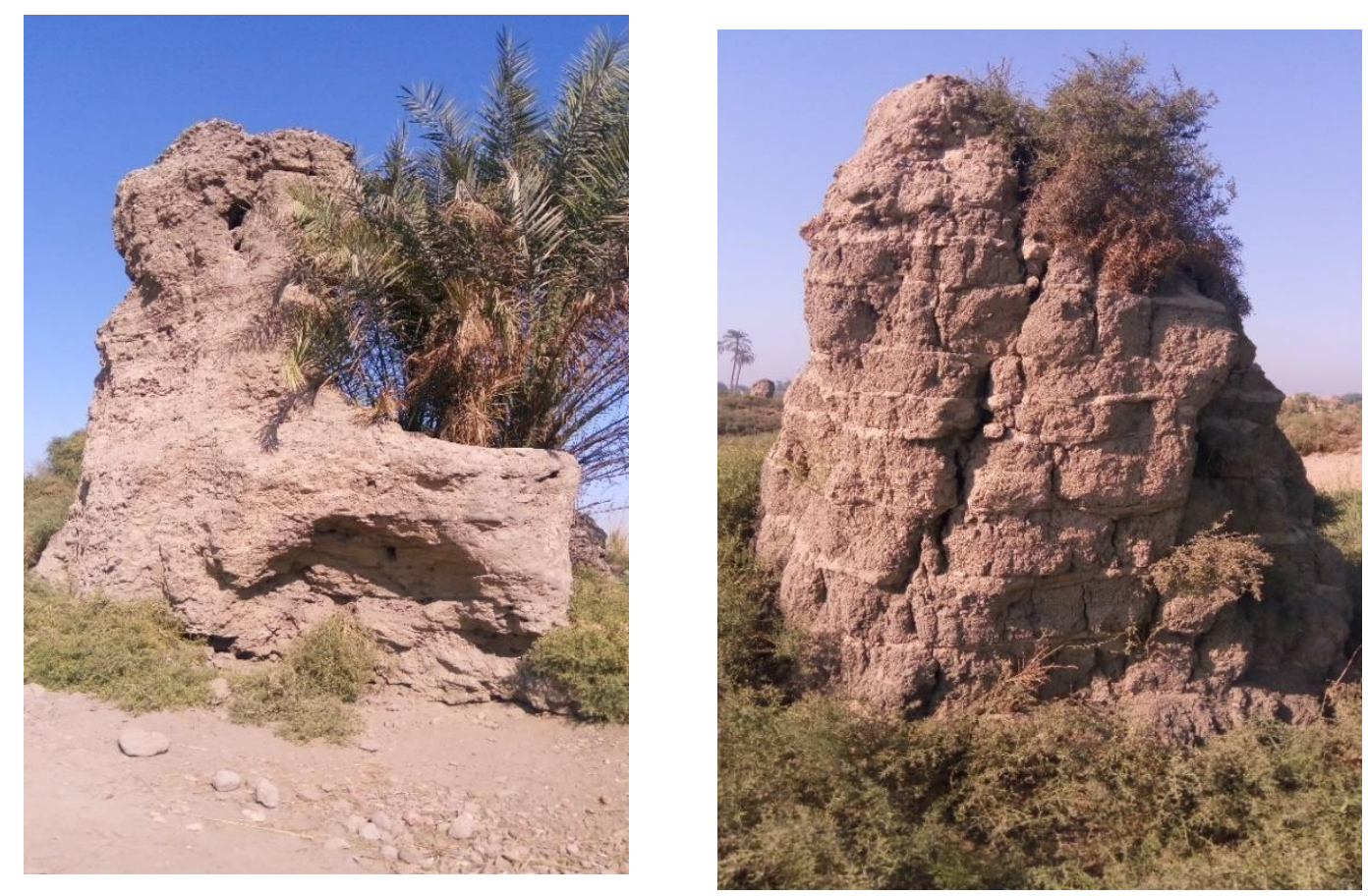

Figure (4): The remains of the Gate of the Sun (left) and the Gate of the Moon (right) of the dromos(Authors' Photograph).

The dromos of Hermes divided the city of Hermopolis Magna into two halves: the north half was called the Citadel ( $\varphi \rho o v$ iov), while the south half was known as the City ( $\pi$ ó $\lambda 1 \varsigma) .{ }^{19}$ Greek papyri mention that the great Hermaion was approached by the great dromos of Hermes, which leads straight forward to the pronaos of the temple. ${ }^{20}$ Baily suggested that the ground of the dromos was paved more than one time during the Ptolemaic Period, as many blocks of stone that date back to the reign of king Akhenaten, better known as the Talatat, and the Late Period were uncovered. ${ }^{21}$

The intersection of the dromos with Antinoe Street already divided the city in four unequal districts (amphodai). The two quarters on the north were called Phrourion East and Phrourion West, while the southern districts were named Polis East and Polis West. The northern amphoda were dominated by the sacred precinct of the god Hermes-Thoth, while the southern by domestic houses. ${ }^{22}$

\footnotetext{
${ }^{18}$ Medini 2011: 5.

${ }^{19}$ Spencer 1982: 74.

${ }^{20}$ SPP 5.81.7-8.

${ }^{21}$ Baily 1991: 20.

${ }^{22}$ Baily 1983: 38.
} 


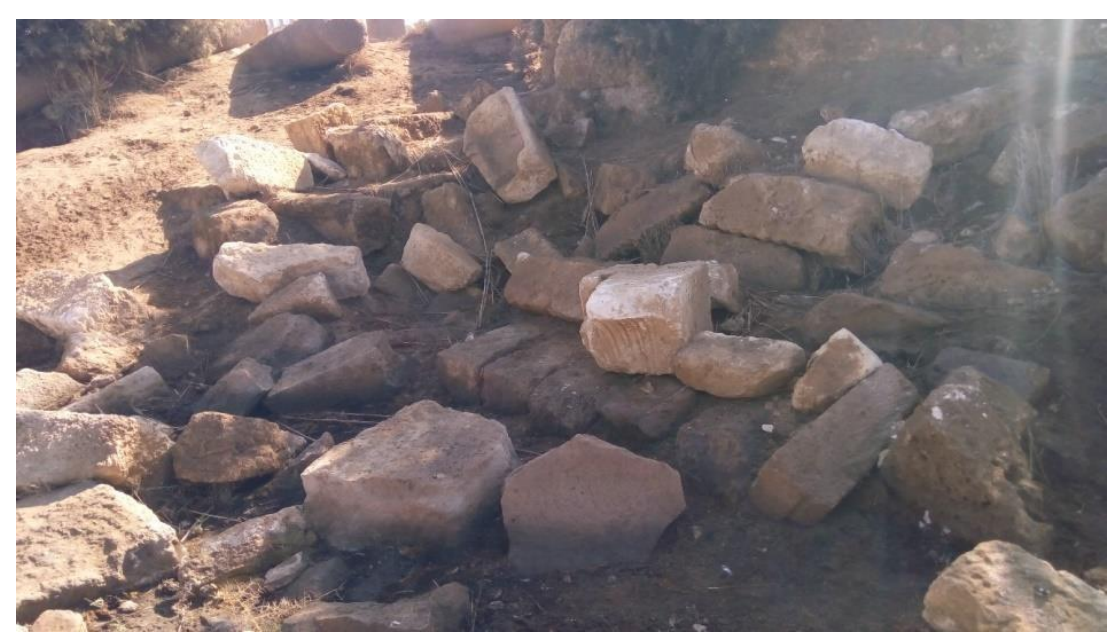

Figure (5): The remains of Tallatat on the ground of the dromos (Authors' Photograph).

A Greek papyrus refers to the full name of the main street of the city as "the stone paved dromos of Hermes the great god". ${ }^{23}$ According to the excavations of the British Museum, the orientation of the dromos differed from the end of the Dynastic Period (2920-342 BC) and was ignored in favour of the Greek-Roman layout. According to the mission's report, the dromos was 2 meters higher than the Antinoe street. $^{24}$ A pylon was demolished to give more space for the paved way and its secondary buildings. ${ }^{25}$

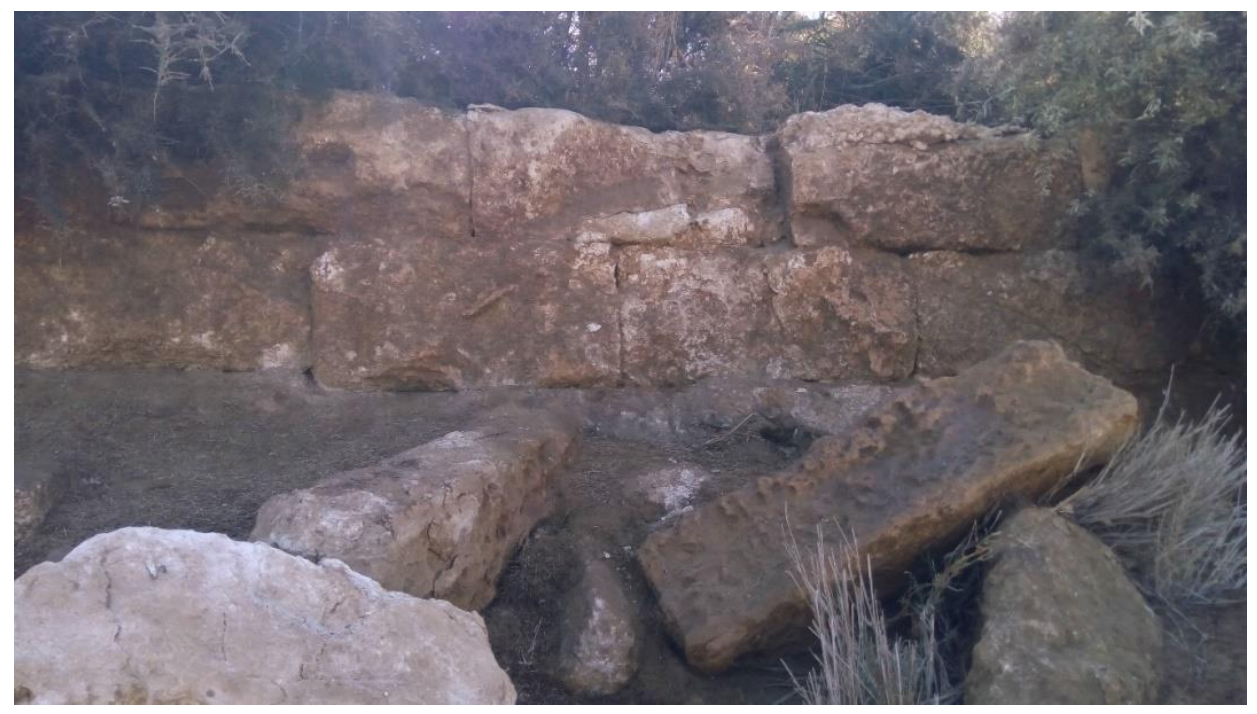

Figure (6): The elevation of the dromos above the ground (Authors' photograph).

Buildings were constructed alongside the dromos within the temple complex; some of these structures were exposed as coin-hoard, which dates back to the early second century AD. Near the intersection with Antinoe Street, the large Komasterion was erected beside the dromos in the second century AD. Other 
buildings were also built on both sides of the dromos. Some of these buildings still remain in situ, though in a bad state of preservation, while the majority is only listed in Greek papyri. ${ }^{26}$

Baily demonstrated that most of these buildings like the Komasterion, Hadrianeion, and the temple of Aphrodite were located on the east side of the dromos of Hermes. ${ }^{27}$ Like the dromoi of Soknopaiou Nesos (Dime) and Alexandria, the dromos of Hermes at Hermopolis Magna was higher than the neighbor structures (fig 6 ), it ran alongside the paved area and on the north side of the Komasterion, there were steps on both sides of the dromos. On the south-end side of the dromos there is a one meter ramp leading onto the Sphinx Gate. ${ }^{28}$

The crossing point of the two main cross and longitudinal streets at Hermopolis Magna was marked with a tetrastylon. ${ }^{29}$ The Repair Papyrus refers to three tetrastyla along Antinoe Street. Only the Great Tetrastylon survives; it has four red granite columns, the trunk of the columns is six meters, resting on a onemeter-high base, and the Corinthian capital measures a meter in height, and marked the junction of the dromos with Antinoe Street. It appears that the Aphorodisias marked the intersection of the dromos of the temple of Aphrodite with the main street. $^{30}$

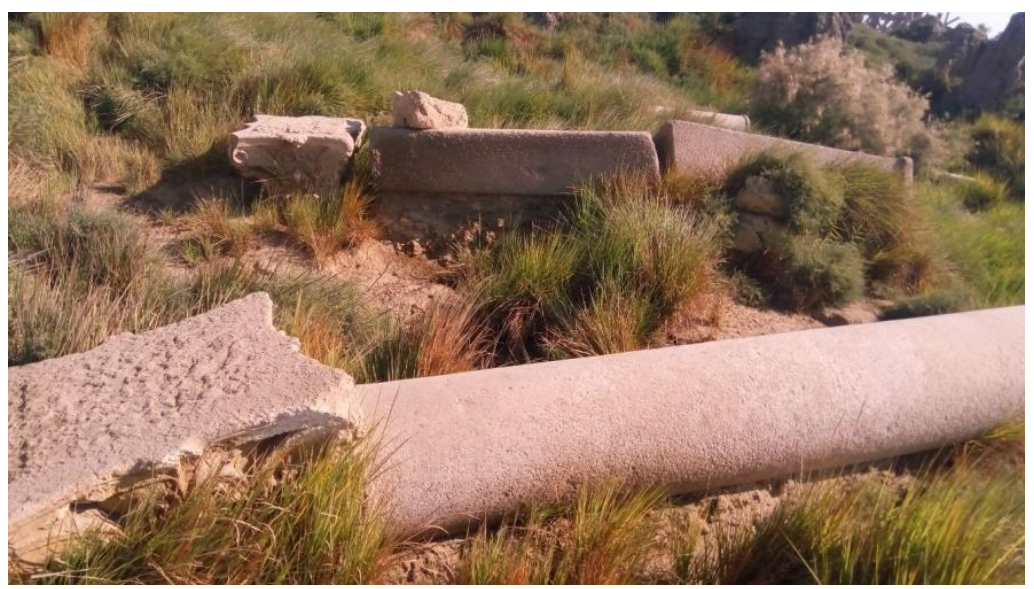

Figure (7): The remains of the Grand Tetrastyle (Authors' Photograph).

A Greek inscription on the pedestal of one of the four columns of the tetrastylon provides information about the history of the tetrastylon. It records the dedication of the Great Tetrastylon by Pactumeius Magnus, prefect of Egypt in AD 176-180, to Marcus Aurelius and Commodus. ${ }^{31}$ Letronne suggests that the inscription belongs to an honorific column. ${ }^{32}$ Later on, an Antonine Komasterion was built to the south of the Ptolemaic bastion at the

\footnotetext{
${ }^{26}$ SPP 5.81.7-8.

${ }^{27}$ Baily 1991: 25.

${ }^{28}$ Medini 2011: 5.

${ }^{29}$ Alston 2002: 132.

${ }^{30}$ Roeder 1959: 104.

${ }^{31}$ Bailey 1983: 29-30.

${ }^{32}$ Letronne 1974: 437.
} 
intersection of the dromos of Hermes with Antinoe Street. ${ }^{33}$ A Greek papyrus datable to AD 19 confirms that the dromos of the greatest god Hermes at Hermopolis Magna was paved with white limestone. ${ }^{34}$

The use of the dromos as a processional way reflected the incorporation of temples into the public space, where cult images went out of the temple and where priests carried the images of the deities on their shoulders and proceeded into a spectacular tour in the city. During that time, the syncretism of Hermes and Thoth reflects the fusion of Greek and Egyptian cultural traditions. Hermes-Thoth was not the god Thoth of Dynastic Period (2920- 342 BC), but a Hellenized version of the Egyptian cult. As the guide of souls and prominent participant in mummification rites, the cult of Hermes-Thoth enjoyed popularity among the ordinary people in GraecoRoman and late Antique Egypt. ${ }^{35}$ The templewas a closed area and only few people were allowed to enter deep inside it. So, it is known that the purification rite is an essential to enter the sacred places, it was common at the dromos in almost all ancient Egyptian cities to find source of water near the sacred precinct of the temple. In Hermopolis Magna, there is a water conduit along the dromos of Hermes, seven wells, and a pool, indicating that the east and west fountain houses (Nymphaia) were located on the south side of the dromos before entering the scared enclosure (temenos) of the temple of Hermes. ${ }^{36}$

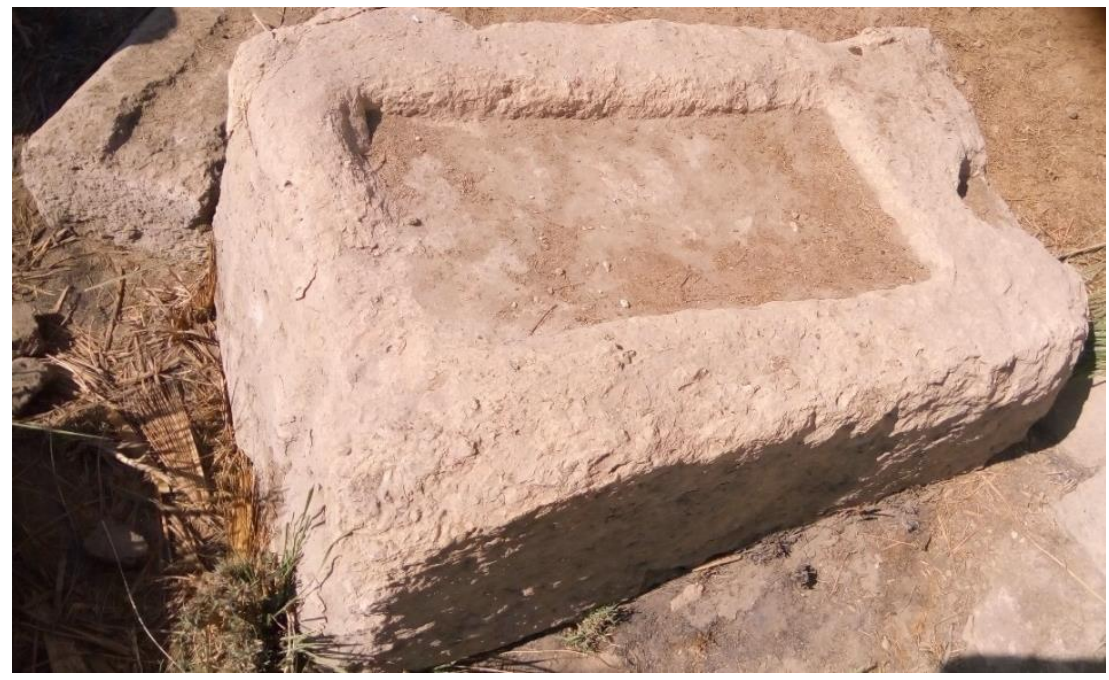

Figure (8): The embalming table of the ibis (Authors' Photograph).

It was also common in other cities like Akoris $^{37}$ to find the Nymphaia on public thoroughfares. The construction of Nymphaia along the dromos occurred also atmany other sites in Egypt, like Tentyris, where a second century AD Nymphaeum was built on the side of Hathor's dromos. At Akoris one finds a water basin on the west side of

\footnotetext{
${ }^{33}$ Abdelwahed 2016: 33.

${ }^{34}$ P.amh.2.98.

${ }^{35}$ Abdelwahed 2016: 37.

${ }^{36}$ McKenzie 2007: 160.

${ }^{37}$ Kawanishi 1989: 120.
} 
the dromos, functioning as the Nymphaia in the other cities. The water pipe alongside the dromos of Hermes is made out of pottery and its diameter is $10 \mathrm{~cm} .{ }^{38}$

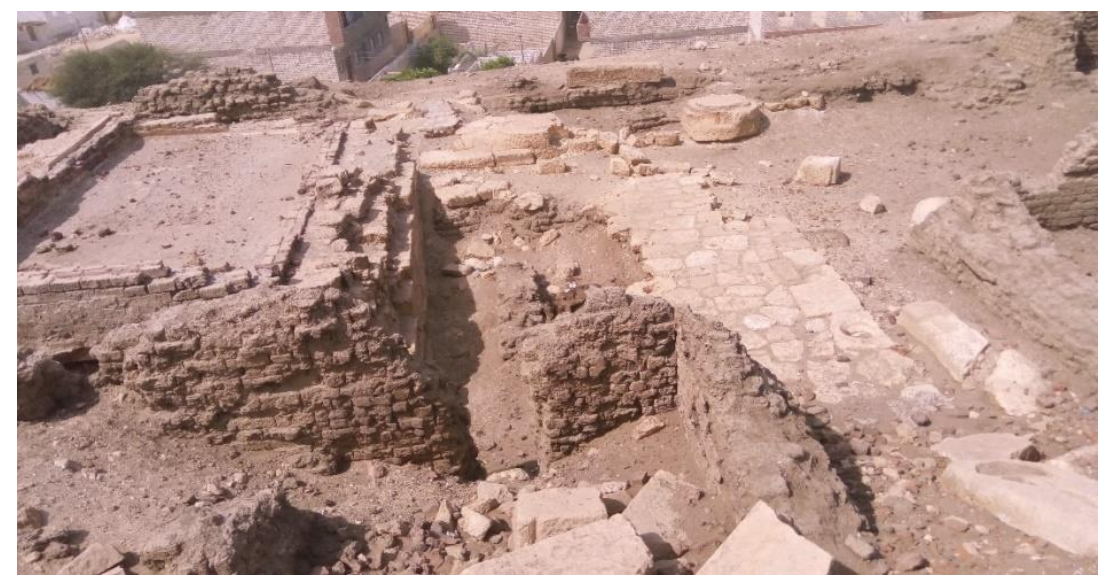

Figure (9): The Nymphaia at the dromos of Akoris (Authors' Photograph).
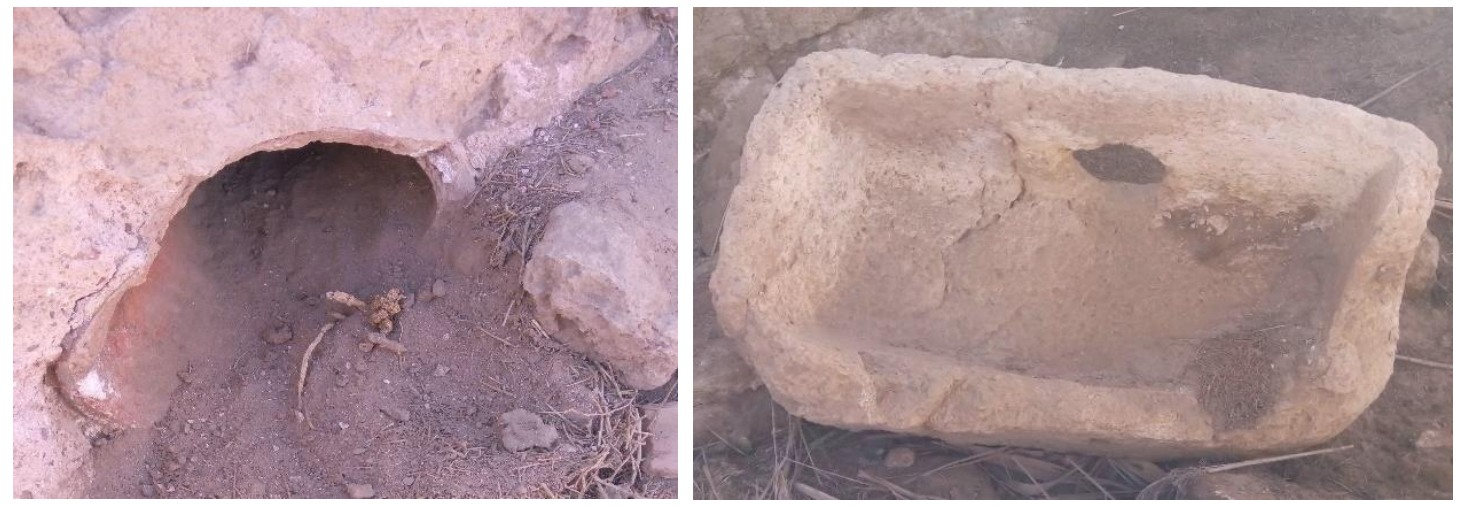

Figure (10): The water pipe and water container at the southern side of the dromos

\section{(Authors' Photograph).}

The dromos of the temple of Hermes was completely decorated under the reign

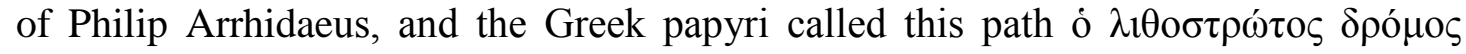

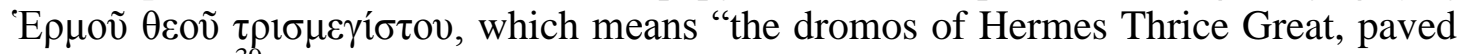
with stones". 39 The Repairs Papyrus, in the national library of Vienna, provides the name of different public buildings built along the dromos of Hermes. This papyrus dates back to the reign of Gallian.

\footnotetext{
${ }^{38}$ Mohamed 2017: 18
}

${ }^{39}$ P. Flor. 1.50 . 


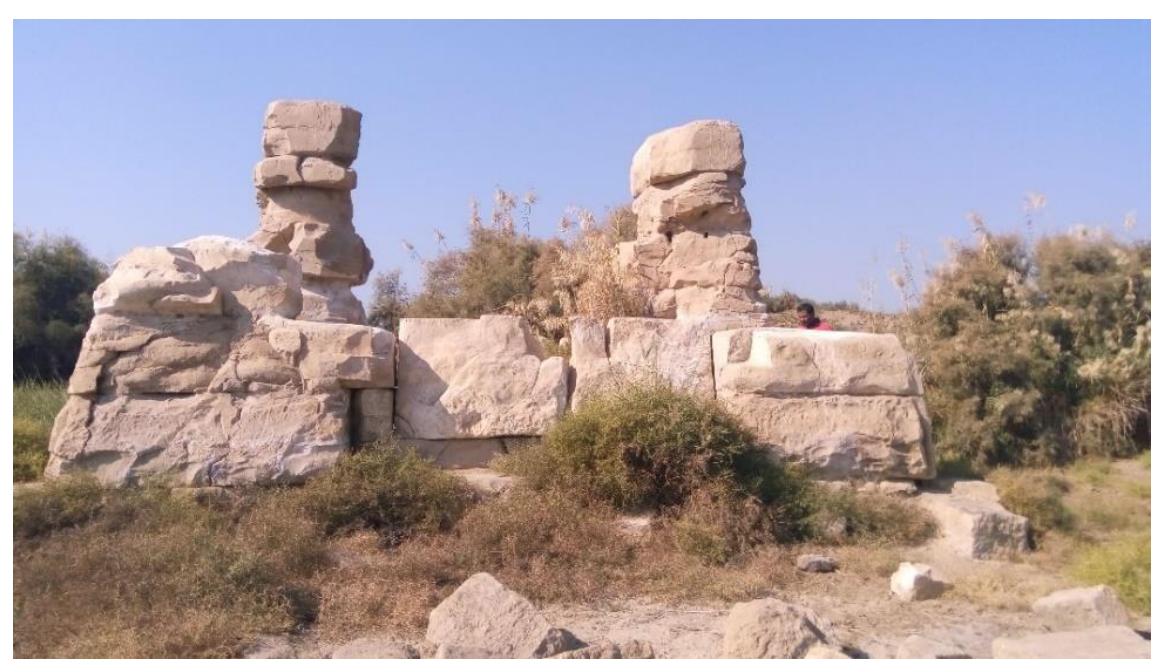

Figure (11): The Western Tetrastyle (Authors' Photograph).

The Antinoeion, Hadrianeion, Macellon, Agora, Serapeum, Nilon, Komasterion, the eastern Nymphai, the western Nymphai, temple of Tyche, the Gate of the Moon, the Exedra, and the Aphrodiseion were all located alongside the dromos. The chapel of Aphrodite dates back to the Dynastic Period and was dedicated to goddess Hathor, butafter the Ptolemies came in power, they identified the Egyptian Hathor with the Greek Aphrodite, as was the case at Akoris. ${ }^{40}$

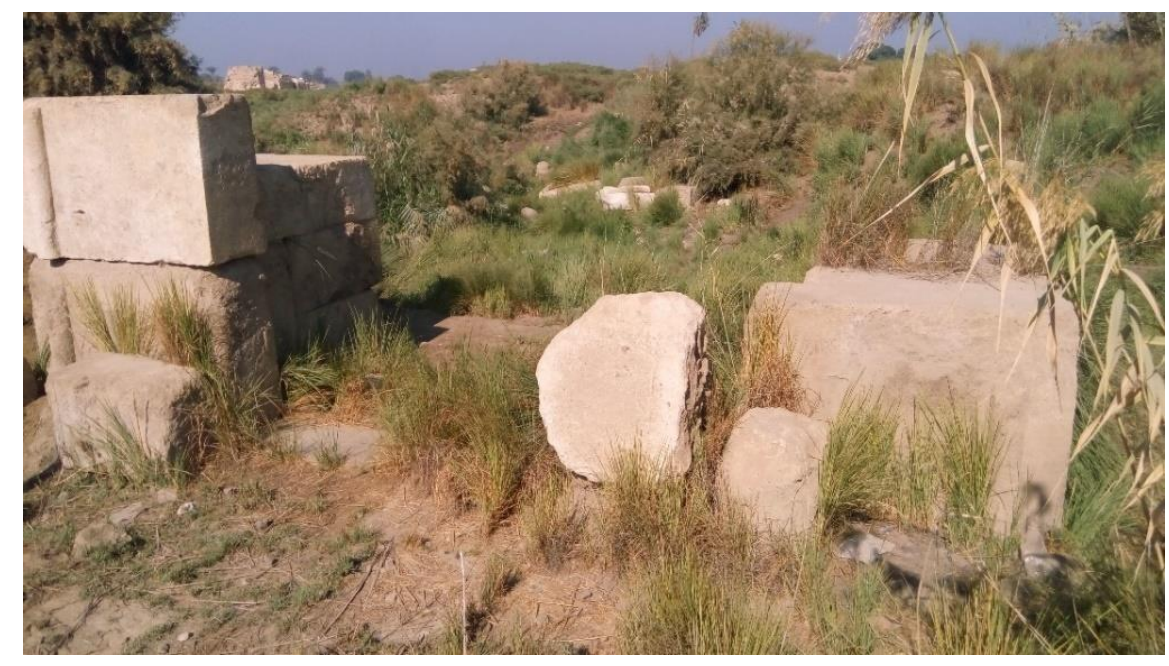

Figure (12): The remains of Aphrodite chapel at the north side of the dromos (Authors' Photograph).

Wace argued that Hathor on the dromos served as a healinggoddess. ${ }^{41}$ The public buildings alongside the dromos were divided into 12 structures starting from the gate of the Sun to the first Tetrastylon, and

\footnotetext{
${ }^{40}$ Mohammed 2017: 32.

${ }^{41}$ Wace 1945: 109.
} 
the second from the tetrastylon to the exedra, the third from the exedra to the Gate of the Moon. ${ }^{42}$

The Bank of Sosias was located on the south side of the dromos near the western tetrastylon. ${ }^{43}$ Strictly speaking, it was located between the grand tetrastylon and the tetrastylon of Athena. The British Museum mission uncovered many coins in containers; these containers were uncovered from the site of the bank. ${ }^{44}$ Based on the excavation activities of Roeder, it seems that the Bank of Sosias was located at the cross point of the dromos with the north-south street of Antinoe near the Grand Teterastylon. ${ }^{45}$ Based on the Repairs Papyrus and the archeological remains, the German archeologists attempted to rebuild the dromos from the east to the west; Based on the archeological remains, it can be said that the Gate of the Sun and the Gate of the Moon were built out of mud brick, and respectively served as the eastern and western doors of the dromos. From the Gate of the Sun to the eastern tetrastylon: the temple of Antinoe, the temple of Hadrian, the agora, and the Macellon were located on southern side, from the eastern tetrastylon towards the west are the remains of the chapel of Serapis which was located on the south side of the dromos and to the west of the Serapeum there was an unidentified colonnaded structure. It is too difficult to identify the building built to the west of this unidentified structure. In $82 \mathrm{BC}$, one Hermaios and his family visited the chapel of Aphrodite and devoted a group of statues at the chapel in honour of the great goddess. ${ }^{46}$

The Temple of Fortune (Tychaion) was located to the west of the chapel of Aphrodite, while the grand tetrastylon was located to the west of the Tychaion. The structures to the west of the grand tetrastylon are unknown. ${ }^{47}$

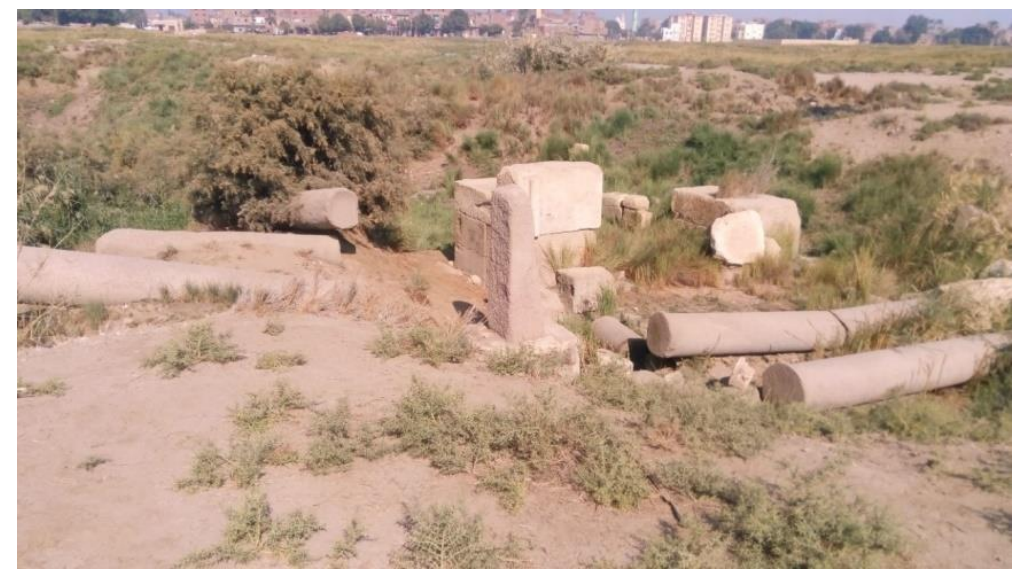

Figure (13): The remains of the tetrastylon of Athena (Authors' photograph).

\footnotetext{
${ }^{42}$ Drew-bear 1913: 23.

${ }^{43}$ P. Oxy 17. 2138.

${ }^{44}$ Spencer 1982: 36.

${ }^{45}$ Roeder 1959: 54.

${ }^{46}$ Roeder 1959: 104.

${ }^{47}$ P.Oxy 17.2138.
} 
A Greek papyrus suggests that the building that was located to the north of the tetrastylon of Athena served as the house of Athena. Also, the Bank of Athena and the house of Athena were built along the dromos. ${ }^{48}$ When comparing the remains of the mud brick buildings on both sides of the dromos of Hermes with those of the dromos of Madinet Maddi, ${ }^{49}$ it can be suggested that it the house of Athena served as a hostel or guest-house on different religious and social occasions. To the east of the Gate of the Moon, the Tychaion is located on the western end of the dromos of Hermes. ${ }^{50}$

On the south side of the two main junctions of Hermopolis Magna there was a bank on the dromos of Hermes. ${ }^{51}$ The governmental affairs and public business seem to have been associated with temples. Temples sometimes had granaries so taxes or payments made in kind were collected and deposited there. ${ }^{52}$ The latest surviving textual testimony of the dromos of Hermes was in Greek papyrus that dates back to A.D $269 .^{53}$

It is worth mention that the word dromos does not appear in Coptic sources. ${ }^{54}$ Spencer noted that a path following the general line of the dromos seems to have been maintained even after the closure of the temple of Thoth/Hermes. Currently, the fine limestone pavement is covered with dirtthat distorted the sacred nature of the street. ${ }^{55}$ The original street has become a dirty track, and the layout of the dromos differed hugely from that of the original processional route due to dramatic changes in its topography by new and modern construction. ${ }^{56}$ Based on the excavations of the German mission, the public activities of the city were concentrated onthe eastern side of the dromos where the imperial cult chapels and the markets stood. ${ }^{57}$ The contrast between the number of structures mentioned in Greek papyri and existing archaeological remains reflect the amount of structures awaited discovery.

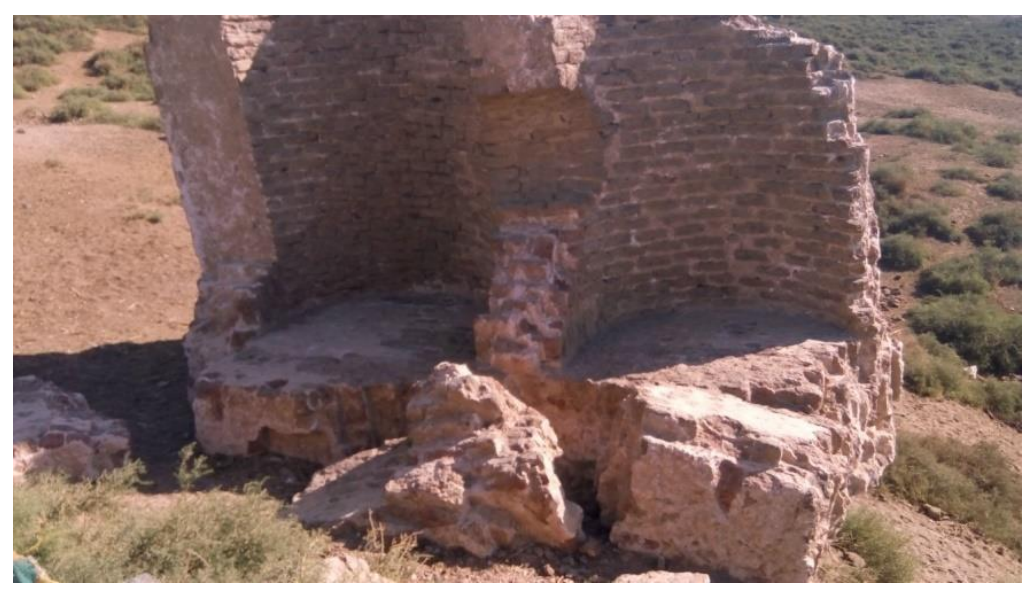

Figure (14): The remains of a building at the south-east side of the dromos (Authors' photograph).

${ }^{48}$ P.Flor. 1.50, 96-7.

${ }^{49}$ Silvano 2013: 39.

${ }^{50}$ Roeder 1959: 102.

${ }^{51}$ P.Oxy. 17. 2138.

${ }^{52}$ Alston 2002: 208.

${ }^{53}$ PFflor. 1.50. 97.

${ }^{54}$ Bomman 2012: 67.

${ }^{55}$ Spencer 1982: 77.

${ }^{56}$ Bomman 2012: 67.

${ }^{57}$ Roeder 1959: 104-6. 
As previously mentioned, the dromos has not been used in connection with Coptic architecture, and it was closely associated with ancient Egyptian temples, which no longer built or operated. A Greek receipt of payment, which dates back to AD 219, confirms the existence of a tetrastylon and a bank on the south side of the paved stone dromos, ${ }^{58}$ which was dedicated to the great god Hermes. ${ }^{59}$ The Greek

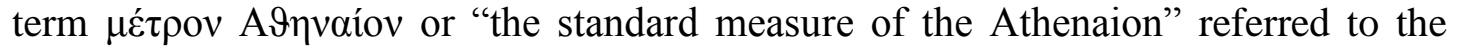
commercial activities conducted on the dromos of Herms, apparently near the tetrastylon of Athena. ${ }^{60}$

\section{Conclusion:}

Together, the papyrological documents and archaeological excavations confirm that the paved stone dromos at Hermopolis Magna was dedicated to the great god Hermes at Hermopolis. The dromos of Thoth-Hermes at Hermopolis Magna was running from east to west. It was the major active area in the daily life activities of the inhabitants in the city. Monumental religious structures, economic constitutions, and cultural activities were centered along at the dromos. The archaeological remains and the Greek papyri suggest a relocation of the dromos from east to west of Hermopolis Magna.

\section{Bibliography:}

Abdelwahed, Y. 2016. "The Soucheia of the Arsinoite Nome.” MJTHR 1/2, 214-223.

Abdelwahed, Y. 2016. Egyptian Cultural Identity in the Architecture of Roman Egypt (30 BC-AD 325), Archaeopress Roman Series 6, Oxford.

Alan, R. 1943. "Short Report on Excavations of The Graeco-Roman Museum made During the Season 1942 at 'Pompey's Pillar': Site of The Temple of Serapis and ofThe Ancient Roman University of Alexandria." BSAA 35, 124-160.

Alan, R. 1957. "A Contribution to the Archaeology of the Western Desert: IV, The Great Serapeum of Alexandria." BJRL 39, 271- 298.

Alston, R. 2002. The City in Roman and Byzantine Egypt, London.

Bailey, D, M. 1983. British Museum Expedition to Middle Egypt, Excavation at ElAshmunein II: Buildings of The Roman Period, London.

Bomman, M. 2012. Memory and Urban Religion in the Ancient World, London.

Camp, J. 1986. The Athenian Agora, London.

Drew-Bear, M. 1913. Le Nome Hermopolite et sa Metropole A L'epoque graecoromaine, Paris.

Habelt, R. 1985. "Athena, Neith, and Thoeris in Greek Documents." ZPE 60, 217- 232.

Kawanishi, H. 1989. Preliminary Reports of Akoris in Middle Egypt, Tokyo.

Letronne, J. A. 1974. Recueil des Inscriptions grecques et latines de L'égypte, 2Vols., Paris.

Lioyd, B, A. 2010. A Companion to Ancient Egypt. The Gods and the Common People, Oxford.

Litinas, N. 2008. Tebtynis III: Vessels Notations from Tebtynis. InstitutFrançais D'archeologie Orientale, Cairo.

\footnotetext{
${ }^{58}$ P.Oxy $17,2138$.

${ }^{59}$ P.Flor. 1.50. 2.

${ }^{60}$ Habelt 1985: 232; Peters 2015: 61.
} 
Magali, G. 2013. Architecture, Astronomy, and Landscapes in Ancient Egypt, Cambridge.

Malgorzata, R. 2012. "Some Remarks on the Historical Topography of Saqqara in the Ptolemaic Period." Études et Travaux XXV, 339-355.

Manning, J, G. 2010. The Last Pharaohs: Egypt under the Ptolemies 305-30 BC, Oxfored.

Mckenzie, J. 2007. The Architecture of Alexandria and Egypt (300 BD-AD 700), Oxford.

Medini, L. 2011. La Topographie religieuse d'Hermopolis a l'epoque graecoromaine. Paris.

Mohamed, H, S. 2017. Tehna el-Gabel (Akoris) in the Greco-Roman Period, An Unpublished MA Thesis, Faculty of Tourism and Hotels, Minia University.

Pfeiffer, S. 2016. Classical Studies, Egyptologie: The Ptolemies; Hellenistic Kingship in Egypt, Oxford.

Rice, E.E. (1983). The Grand Procession Of Plolemy Philadelphus, Oxford.

Richard, H. W. 2000. The Complete Temples of Ancient Egypt, London.

Ridgway, B, S. 1971. "The Athenian Agora: Excavations of 1970”. Hesperia 40/3, 241279.

Riggs, C. 2012. The Oxford Handbook of Roman Egypt: The Imperial Cult of Roman Egypt, Oxford.

Roeder, G. 1959. Hermopolis 1929-1939: Ausgrabungen Der Deutschen Hermpolis-Expedition in Hermopolis, Ober-Ägypten, Hildesheim.

Spencer, A, J. 1982. British Museum Expedition to Middle Egypt, Excavation at ElAshmunein II: The Temple Area, London.

Silvano, F. 2013. "Materiaali in Vertro e Faience dal Quartiere and Ovest del Dromos Di Medinet Madi." Egitto E Vicino Oriente 36, 39-62.

Wace, B. 1945. "Recent Ptolemaic Finds in Egypt: Alexandria.” JHS 65, 106-109.

Wachsmuth, C. 1887. "Zur Topographie von Alexandria." Rheinisches Museum für Philologie 42, 462-466.

Yannis, L. 2003. "Greek Roads: A Commentary on the Ancient Terms." Glotta 79, 1 /4, 137-174. 